\title{
Influence of Nutrient and Environmental Factors on Conidial Germination of Potebniamyces pyri
}

\author{
Q. Liu and C. L. Xiao
}

Department of Plant Pathology, Washington State University, Tree Fruit Research and Extension Center, 1100 North Western Avenue, Wenatchee 98801.

Accepted for publication 3 February 2005.

\section{ABSTRACT}

Liu, Q., and Xiao, C. L. 2005. Influence of nutrient and environmental factors on conidial germination of Potebniamyces pyri. Phytopathology 95:572-580.

Potebniamyces pyri is the causal agent of Phacidiopycnis rot, a postharvest disease of pears. Infection of fruit occurs in the orchard, and symptoms develop during storage. Conidial germination of $P$. pyri in response to nutrient, temperature, wetness duration, relative humidity $(\mathrm{RH})$, and $\mathrm{pH}$ was determined in vitro. Conidia germinated by either budding or developing germ tubes in various concentrations of pear juice solutions. The mode of conidial germination was nutrient-dependent. Low nutrient levels favored budding, whereas high nutrient levels favored germ tube development. Conidia germinated at 0 to $30^{\circ} \mathrm{C}$ but not at $35^{\circ} \mathrm{C}$, with optimum temperature between 20 and $25^{\circ} \mathrm{C}$. Wetness durations of 4 to $5 \mathrm{~h}$ and 6 to $8 \mathrm{~h}$ at optimum temperature were required for budding and developing germ tubes, respectively, and 20 to $24 \mathrm{~h}$ of wetness was required to reach germination peaks. Regardless of temperature, conidia germinated primarily by budding in $10 \%$ pear juice. Secondary conidia, produced by budding of conidia, initially increased their dimensions and later germinated at 0 to $25^{\circ} \mathrm{C}$ in the same manner as mother conidia. No germination of secondary conidia occurred at $30^{\circ} \mathrm{C}$. Germ tubes from conidia elongated at 0 to $25^{\circ} \mathrm{C}$ but not at $30^{\circ} \mathrm{C}$. No germination occurred at $\leq 95 \% \mathrm{RH}$. At $20^{\circ} \mathrm{C}$, conidia germinated only by germ tubes at $98 \%$ $\mathrm{RH}$, and conidia germinated in both manners at $100 \% \mathrm{RH}$ but dominated by germ tubes. In free water $(0.1 \%$ pear juice $)$ the majority of conidia germinated by budding. After 5 days at $0^{\circ} \mathrm{C}$, conidia germinated at $100 \%$ $\mathrm{RH}$ but not at $\leq 98 \% \mathrm{RH}$. More than $80 \%$ of conidia germinated in $10 \%$ pear juice at $\mathrm{pH} 4$ to 7 after $24 \mathrm{~h}$ at $20^{\circ} \mathrm{C}$, whereas there was $<50 \%$ germination at $\mathrm{pH} 3$. Low $\mathrm{pH}$ favored budding, whereas high $\mathrm{pH}$ favored developing germ tubes. These results contribute to a better understanding of the biology and ecology of the fungus and environmental conditions required for infection of fruit.

Additional keywords: Phacidiopycnis piri, Pyrus communis, spore germination.
The discomycete Potebniamyces pyri (Berkeley \& Broome) Dennis, anamorph Phacidiopycnis piri (Fuckel) Weindlmayr (6), was originally described under the name Phacidiella discolor by Potebnia (17). The fungus has been reported to be associated with bark necrosis and branch cankers on apple (Malus $\times$ domestica Borkh) and pear (Pyrus communis L.) trees $(3,4,8,17,21,26)$. Potebniamyces pyri also is the causal agent of Phacidiopycnis rot, a postharvest fruit rot disease of apple and pear (20). The fungus has previously been reported only in Europe and India $(19,20)$. $P$. pyri has two types of conidia formed in conidiomata: microconidia and macroconidia. Microconidia do not germinate (21) and are considered spermatia in the life cycle of the fungus (24). Macroconidia germinate in two different manners: one is budding to produce free, secondary spores, which further produce germ tubes and develop into hyphae $(17,21)$; the other is developing germ tubes, which is considered an exceptional manner of conidial germination (21). There is no information on environmental factors affecting conidial germination of $P$. pyri (20).

Phacidiopycnis rot has recently been reported in the United States $(25,27)$ and has been determined to be an important component of storage decay in 'd'Anjou' pears, one of the major winter pear cultivars grown in the United States (27). A 2-year survey indicated that Phacidiopycnis rot accounts for an average of $30 \%$ of the decay in packed 'd'Anjou' pears during the storage period from March to May in Washington State. It has been

Corresponding author: C. L. Xiao; E-mail address: clxiao@wsu.edu

DOI: 10.1094/PHYTO-95-0572

(C) 2005 The American Phytopathological Society suggested that Phacidiopycnis rot should be considered one of the targets for control of postharvest diseases in d'Anjou pears in the region (27). Phacidiopycnis rot causes three types of symptoms in d'Anjou pear fruit: stem-end rot, calyx-end rot, and skin woundassociated rot, resulting from infections at stem, calyx of the fruit, and wound on the fruit surfaces, respectively. Infection of fruit by the fungus occurs in the orchard, and symptoms develop during storage (27). The fungus is found to be associated with dead bark, twigs, and spurs of pear trees in pear orchards in Washington State. Pycnidia of the fungus containing viable conidia are available throughout the pear fruit-growing season, and apothecia of the fungus have also been observed but at a low frequency (28). Because conidia are the main type of inoculum responsible for infection of fruit during the pear-growing season and spore germination is prerequisite for infection of pear fruit by the fungus, an understanding of environmental conditions required for spore germination is needed in order to further understand conditions required for infection of fruit by the fungus and to develop relevant measures for control of the disease. The objectives of this study were to determine (i) the effect of nutrient level on germination of macroconidia; (ii) the effects of temperature and wetness duration on germination of macroconidia; (iii) the effects of temperature and wetness duration on germination of secondary conidia, produced by budding of macroconidia; and (iv) the effects of relative humidity $(\mathrm{RH})$ and $\mathrm{pH}$ on germination of macroconidia.

\section{MATERIALS AND METHODS}

Isolates and production of pycnidia. Two isolates of $P$. pyri, 210 and 745 , were used throughout this study. Isolate 210 was 
recovered from a decayed d'Anjou pear fruit collected from a commercial fruit packinghouse in Wenatchee, WA. Isolate 745 was derived from a single ascospore from an apothecium of the fungus on dead bark sampled from a d'Anjou pear tree in a pear orchard in Peshastin, WA. The voucher specimen from which 745 was derived is deposited at the Washington State University Mycological Herbarium (accession no. WSP 70479), and the living culture is deposited at ATCC (accession no. MYA-3318). Mycelium plugs removed from cultures on pear juice agar $(200 \mathrm{ml}$ of freshly made pear juice, $15 \mathrm{~g}$ of agar, $3 \mathrm{~g}$ of $\mathrm{CaCO}_{3}$, and $800 \mathrm{ml}$ of deionized water) or oatmeal agar (OMA, $60 \mathrm{~g}$ of finely ground iron- and zinc-fortified oatmeal [Gerber, Fremont, MI] and $15 \mathrm{~g}$ of agar in $1,000 \mathrm{ml}$ of deionized water and sterilized for $90 \mathrm{~min}$ ) were stored in sterile water at $4{ }^{\circ} \mathrm{C}$ and $15 \%$ glycerol solution at $-80^{\circ} \mathrm{C}$.

To produce pycnidia and conidia, 4-mm mycelium plugs were removed with a sterile cork borer from the leading edges of $P$. pyri colonies on 7-day-old OMA cultures, and one such plug was placed in the center of each $100-\mathrm{mm}$ petri plate containing approximately $25 \mathrm{ml}$ of OMA. Inoculated plates were sealed with Parafilm (Pechiney Plastic Packaging, Chicago, IL) and incubated at $20^{\circ} \mathrm{C}$ under 12-h alternating cycles of dark and fluorescent light $\left(10 \mathrm{Wm}^{-2}\right)$ (29). Pycnidia that formed on 10- to 12-week-old OMA cultures were used to make conidial suspensions in all experiments.

Preparation of conidial suspensions for germination studies. Preliminary studies indicated that macroconidia of $P$. pyri were able to germinate in sterile deionized water but at a low percentage, and additional nutrients (pear juice) stimulated conidial germination of the fungus. In this study, unless otherwise specified, a $10 \%$ pear juice solution was used to make conidial suspensions to study germination in response to environmental conditions. A macroconidial suspension was prepared as follows: three or four pycnidia at a time were collected and crushed in a drop of designated solution (a pear juice solution or pure water) on a glass slide, and the released macroconidia were washed into a $20-\mathrm{ml}$ beaker with the same solution. The conidial suspension was adjusted to 5 to 10 macroconidia per field at $\times 200$ magnification under a microscope. A $45-\mu \mathrm{l}$ aliquot of the macroconidial suspension was delivered by a pipette onto each of the two wells (circles) (10-mm-diameter and 1-mm-depth each circle) on an Esco fluoro slide (Erie Scientific, Portsmouth, NH). Three circles on two slides (two on one slide and one on the other) were used as three replicates for each treatment. One such slide was placed on a moist Whatman filter paper $(7.0 \mathrm{~cm}$ in diameter, Whatman Limited, England) in a 90-mm-diameter petri plate. Petri plates with slides were sealed with Parafilm before they were placed into incubators at designated temperatures. Preparation of inoculum and slides for germination studies was the same as described here throughout the study, unless otherwise specified.

Observation of macroconidial germination. In this study, the secondary spores, produced by budding of mother conidia, are called secondary conidia, which are referred to as budded, secondary spores by Southee and Brooks (21). A macroconidium was considered to have germinated by budding when secondary conidia were clearly recognized to be budded by the mother conidia (secondary conidia are either still attached to the mother conidia or detached but aggregate and surround the mother conidia) under a compound microscope at $\times 200$ magnification. A macroconidium was considered to have germinated by germ tube(s) when the length of a germ tube was at least half of the length of the macroconidium. One hundred macroconidia were examined in each of three replicates for each treatment. The percentage of macroconidia germinated by budding or by developing germ tubes was determined, and the number of germ tubes produced by each macroconidium was noted. Lengths of germ tubes were recorded based on 20 randomly selected germ tubes per 100 macroconidia. If not specified, germination of macroconidia was assessed as described here throughout the study.
Effects of nutrient levels on germination of macroconidia. To determine conidial germination in response to nutrient levels, freshly made pear juice was used in the study. D'Anjou pears that had been stored for 6 months at $0^{\circ} \mathrm{C}$ were used to make the pear juice, which was then stored at $-20^{\circ} \mathrm{C}$. Before its use, the pear juice stock was sterilized by passing through a 0.45 - $\mu \mathrm{m}$-pore-size Corning filter (Corning, NY). A series of pear juice solutions at concentrations of $0.1,1,10,30,50$, and $100 \%$ was prepared with the pear juice stock solution, and sterile deionized water was used as a control. Macroconidial suspensions were prepared with corresponding nutrient solutions. Conidial germination slides were prepared as described previously. Slides from each treatment were incubated at 0 and $20^{\circ} \mathrm{C}$ in this experiment. Germination of macroconidia was examined every $6 \mathrm{~h}$ up to $24 \mathrm{~h}$ at each temperature. At $0^{\circ} \mathrm{C}$, macroconidial germination was also examined after $36 \mathrm{~h}$, and at 2, 4, and 5 days of incubation. This experiment was performed twice.

Effects of temperature and wetness duration on germination of macroconidia. Germination slides were placed in incubators at $0,5,10,15,20,25,30$, and $35^{\circ} \mathrm{C}$. After incubation for 4 , $5,6,8,10,12,16,20$, and $24 \mathrm{~h}$ at each temperature, two petri plates consisting of two germination slides (a total of three wells containing conidial suspensions) were removed from each temperature. Germination of macroconidia was examined as described previously. A preliminary observation indicated that conidia of the fungus germinated very slowly at low temperatures. Thus, in addition, conidial germination was also examined after 2 and 4 days of incubation at $5^{\circ} \mathrm{C}$ and 2,4 , and 6 days of incubation at $0^{\circ} \mathrm{C}$. Because it took more than $1 \mathrm{~h}$ to complete examinations of conidial germination under a microscope, some germination slides were stored in a refrigerator at $4^{\circ} \mathrm{C}$ before examination. This was to slow down the germination process and minimize the influence of delay of examination on conidial germination. This experiment was performed twice.

Effects of temperature and wetness duration on germination of secondary conidia. Germination slides were placed in incubators at $0,10,20,25$, and $30^{\circ} \mathrm{C}$. Preliminary studies indicated that secondary conidia, produced by budding of macroconidia, did not germinate in $16 \mathrm{~h}$ of incubation. In this experiment, germination of secondary conidia was examined after incubation for $16,20,24,30,36$, and $42 \mathrm{~h}$ at 20,25 , and $30^{\circ} \mathrm{C} ; 24,36,48$, 60,72 , and $84 \mathrm{~h}$ at $10^{\circ} \mathrm{C}$; and $7,8,9,10,11$, and 12 days at $0^{\circ} \mathrm{C}$. Our preliminary studies also indicated that secondary conidia germinated in the same manner as mother conidia. Thus, a secondary conidium was considered to have germinated by budding when it budded and produced new, secondary conidia (second generation of bud conidia) that were attached to the mother conidia. A secondary conidium was considered to have germinated by germ tube(s) when a germ tube was equal to or longer than half of its length. Germination of 100 secondary conidia in each well was determined, and three wells from each temperature $x$ time combination were observed at each observation time. The percentage of secondary conidia germinated by budding or by developing germ tubes was recorded. Because different generations of secondary conidia may coexist, in order to avoid the second generation of secondary conidia for measurement of germ tube elongation, the range of lengths of germ tubes in a few fields was determined first and then the lengths of the 10 longest germ tubes in each replicate were recorded at $\times 200$ magnification. This experiment was performed twice.

Effect of RH on germination of macroconidia. Conidial germination was examined at 92, 95, 98, and $100 \% \mathrm{RH}$ at 0 and $20^{\circ} \mathrm{C}$ in this study. RH levels were maintained by glycerol solutions at different concentrations (13). A designated glycerol solution was placed in a Baker's Secret loaf pan $\left(21\right.$ by 11 by $6 \mathrm{~cm}^{3}$; World Kitchen, Inc., Elmira, NY), and a cage made with metal wire was placed in the pan to support spore germination slides. Pans were sealed with plastic bags and placed in incubators at the 
designated temperatures. Glycerol concentrations to maintain corresponding $\mathrm{RH}$ levels were determined with a Watchdog 450 data logger (Spectrum Technologies, Inc., Plainfield, IL) at each temperature. The corresponding concentrations of glycerol solutions for selected RH levels were $30 \%$ for $92 \% \mathrm{RH}, 24 \%$ for $95 \% \mathrm{RH}$, and $18 \%$ for $98 \% \mathrm{RH}$ at $20^{\circ} \mathrm{C}\left( \pm 0.5^{\circ} \mathrm{C}\right)$, respectively; and $40 \%$ for $92 \% \mathrm{RH}, 37 \%$ for $95 \% \mathrm{RH}$, and $35 \%$ for $98 \% \mathrm{RH}$ at $0^{\circ} \mathrm{C}$ $\left( \pm 0.5^{\circ} \mathrm{C}\right)$, respectively. $\mathrm{RH}$ at $100 \%$ was maintained with water. The RH treatments were set up $24 \mathrm{~h}$ before spore germination slides were placed in the pans. Germination slides were first airdried for $30 \mathrm{~min}$ in a laminar hood and then transferred to loaf pans at a designated RH. Preliminary experiments indicated that if $10 \%$ pear juice was used to make conidial suspensions, free water formed at wells on the slides that had been dried for $30 \mathrm{~min}$ before they were placed in the RH chamber. Thus, in the RH experiment, macroconidial suspensions were prepared with a $0.1 \%$ pear juice solution to avoid the problem. Two slides (three circles containing conidial suspensions) were removed from each $\mathrm{RH}$ level at $20^{\circ} \mathrm{C}$ every $12 \mathrm{~h}$ up to $60 \mathrm{~h}$. At $0^{\circ} \mathrm{C}$, slides were removed daily from the $100 \% \mathrm{RH}$ treatment and every 2 days from the other three RH levels. In addition, slides with conidial suspensions without air drying were incubated in moist petri plates at 0 and $20^{\circ} \mathrm{C}$, and germination of macroconidia was examined using the same sampling scheme for RH treatments. This experiment was performed twice.
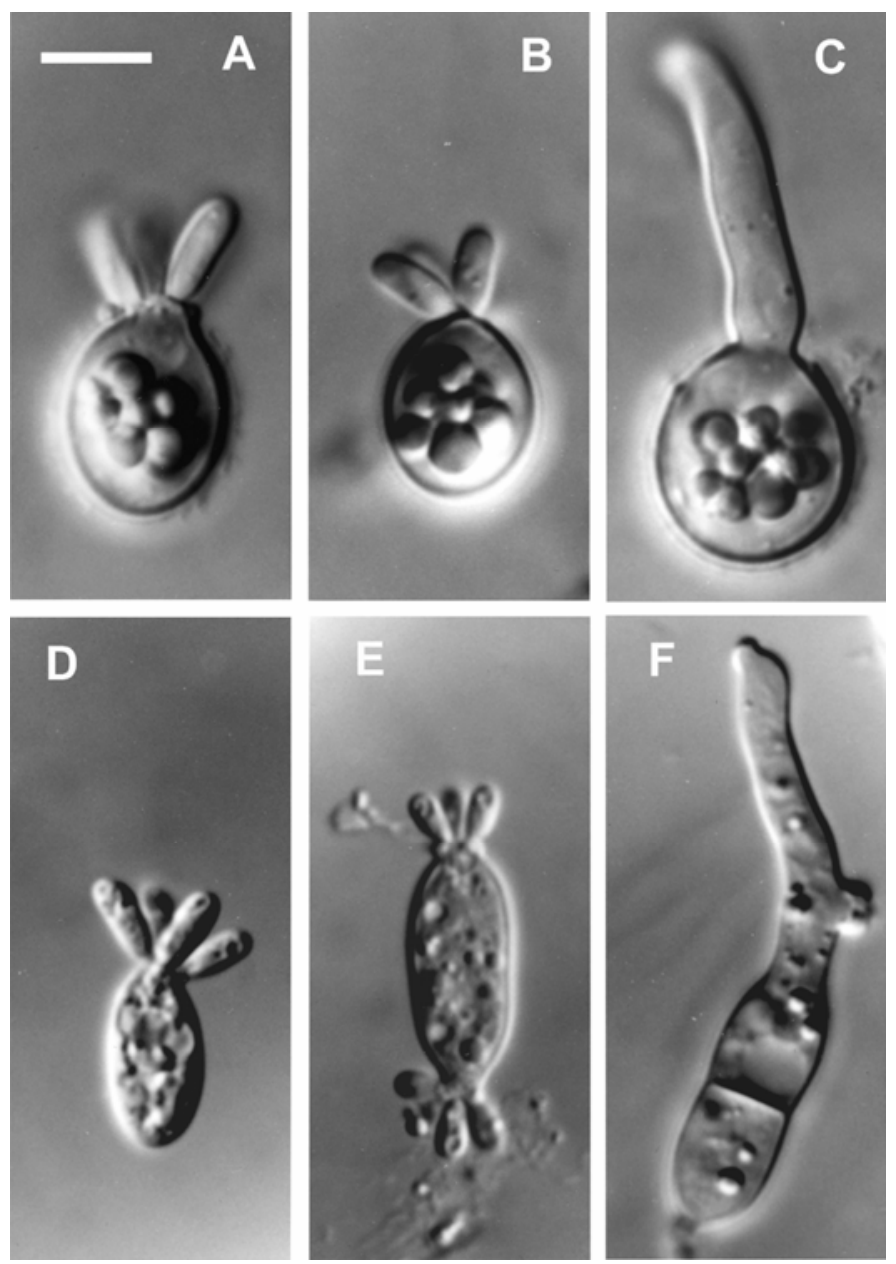

Fig. 1. Modes of conidial germination of Potebniamyces pyri: A and B, budding of macroconidia to produce one to several secondary conidia after $18 \mathrm{~h}$ of incubation at $20^{\circ} \mathrm{C}$; $\mathbf{C}$, formation of a germ tube from a macroconidium after $18 \mathrm{~h}$ of incubation; $\mathbf{D}$ and $\mathbf{E}$, budding of secondary conidia at either one end or both ends to produce the second generation of secondary conidia; and $\mathbf{F}$, formation of a germ tube from a secondary conidium after $36 \mathrm{~h}$ of incubation. Bar $=5 \mu \mathrm{m}$.
Effects of $\mathbf{p H}$ on macroconidial germination. The $\mathrm{pH}$ of a $10 \%$ pear juice solution was adjusted to $3,4,5,6$, and 7 with $1 \mathrm{~N}$ $\mathrm{NaOH}$ and $1 \mathrm{~N}$ succinic acid (10) using Corning $\mathrm{pH}$ Meter 440 (Corning, NY). Pear juice solutions at various $\mathrm{pH}$ levels were sterilized by passing through a $0.45-\mu \mathrm{m}$-pore-size Corning filter (Corning), after which they were used to prepare macroconidial suspensions. Germination of macroconidia was determined after incubation for 12 and $24 \mathrm{~h}$ at $20^{\circ} \mathrm{C}$. This experiment was performed twice.

Data analysis. Analysis of variance performed with SAS PROC GLM (version 8.2, SAS Institute, Cary, NC) was used to assess effects of nutrient levels, temperature and wetness duration, and $\mathrm{pH}$ on conidial germination. Treatment means were separated using Fisher's protected least significant difference $(P=$ 0.05). A $t$ test was performed with either SAS PROC MEANS to compare percent germination by budding versus percent germination by germ tube within a treatment or PROC TTEST to compare percent germination between two specific treatments $(P=0.05)$. A preliminary analysis of variance indicated no significant differences between the experimental runs, so the data from the two runs of each experiment were pooled for analysis. All data in percentage were arcsine-transformed prior to analysis (9).

\section{RESULTS}

Mode of conidial germination. Macroconidia germinated in two different manners: by either budding or developing germ tubes (Fig. 1). For germination by budding, one macroconidium budded to form one to several secondary conidia (Fig. 1A and B). Budding occurred at both ends of a conidium, but it was observed most frequently at one end. Budding did not occur at locations other than both ends of the conidium. In the second manner of germination, a macroconidium developed germ tubes from either the ends or other locations on the conidium. A macroconidium developed one to three germ tubes in a pear juice solution on a glass slide (Fig. 1C), while it developed as many as five germ tubes on the surface of potato dextrose agar. Secondary conidia, produced by budding of mother conidia, initially increased their dimensions and later germinated in the same modes as the mother conidia, but budding at both ends was more commonly seen (Fig. 1E). In general, a secondary conidium produced only one to two germ tubes in pear juice solutions (Fig. 1F).

Effect of nutrient levels on macroconidial germination. Macroconidia of both isolates were able to germinate in pure water but at a low percentage; only 25.4 and $22.7 \%$ of macroconidia germinated after incubation for $24 \mathrm{~h}$ at $20^{\circ} \mathrm{C}$ for isolates 210 and 745, respectively (Fig. 2D). Nutrient levels (pear juice concentrations) significantly $(P<0.0001)$ affected conidial germination, and $\geq 1 \%$ pear juice solutions significantly stimulated conidial germination. After incubation for $24 \mathrm{~h}$ at $20^{\circ} \mathrm{C}$, the total percentages of germination of both isolates in $\geq 1 \%$ pear juice solutions were significantly higher than in $0.1 \%$ pear juice solution, and there was no significant difference in the percentage of germination among concentrations $\geq 1 \%$ (Fig. 2D).

Nutrient levels significantly affected the mode of conidial germination of $P$. pyri at both 20 and $0^{\circ} \mathrm{C}$ (Figs. 2 and 3). After $24 \mathrm{~h}$ of incubation at $20^{\circ} \mathrm{C}$, the percent conidia that germinated by budding increased as the pear juice concentration increased from 0 to $1 \%$ (isolate 210: $y=32.12+53.91 x, R^{2}=0.6573, P<$ 0.0001 ; isolate 745: $y=18.93+70.95 x, R^{2}=0.8712, P<0.0001$ ) and then decreased as the pear juice concentration increased from 1 to $100 \%$ (isolate 210: $y=93.64-0.62 x, R^{2}=0.8445, P<$ 0.0001 ; isolate 745: $\left.y=92.27-0.82 x, R^{2}=0.8236, P<0.0001\right)$. The percent conidia that germinated by germ tubes increased as the pear juice concentration increased (isolate 210: $y=-1.07+$ $0.64 x, R^{2}=0.9382, P<0.0001$; isolate $745: y=0.06+0.80 x$, $R^{2}=0.6971, P<0.0001$ ) (Fig. 2D). Germination by budding reached its peak after $12 \mathrm{~h}$ of incubation at $20^{\circ} \mathrm{C}$, while ger- 
mination by germ tubes reached its peak after $18 \mathrm{~h}$ of incubation (Fig. 2).

At $0^{\circ} \mathrm{C}$, conidial germination in response to nutrient levels followed a similar trend as observed at $20^{\circ} \mathrm{C}$ (Fig. 3). After $120 \mathrm{~h}$ of incubation at $0^{\circ} \mathrm{C}$, the percent conidia that germinated by budding increased as the pear juice concentration increased from 0 to $1 \%$ (isolate 210: $y=26.25+45.66 x, R^{2}=0.7048, P<$ 0.0001 ; isolate 745: $y=26.01+55.88 x, R^{2}=0.6971, P<0.0001$ ) and then generally decreased as the pear juice concentration increased from 1 to $100 \%$ (isolate 210: $y=74.46-0.45 x, R^{2}=$ $0.5209, P<0.0001$; isolate $745: y=90.63-0.68 x, R^{2}=0.8887$, $P<0.0001)$. The percent conidia that germinated by germ tubes increased with the pear juice concentration (isolate 210: $y=18.44+$ $0.35 x, R^{2}=0.3902, P<0.0001$; isolate $745: y=0.96+0.49 x$, $R^{2}=0.9140, P<0.0001$ ) (Fig. 3D). After $120 \mathrm{~h}$ of incubation at $0^{\circ} \mathrm{C}, 70$ to $80 \%$ of conidia germinated by budding in $1 \%$ pear juice solution, whereas $>50 \%$ of conidia germinated by germ tubes in $100 \%$ pear juice solution (Fig. 3D).

Effects of temperature and wetness duration on macroconidial germination. Temperature and wetness duration significantly affected total germination and percentage of budding in the total germination (Table 1). The difference in the total germination between the two isolates was wetness-dependent, but at $24 \mathrm{~h}$ of wetness duration there was no significant difference in total germination between the two isolates (Table 1; Fig. 4E and F). At wetness duration of $24 \mathrm{~h}$, there was no significant difference in the percentage of budding in the total germination, regardless of temperature (Table 1).

Conidia germinated at temperatures from 0 to $30^{\circ} \mathrm{C}$ by either budding or developing germ tubes (Fig. 4). At $0^{\circ} \mathrm{C}$, macroconidia germinated very slowly; conidial germination did not occur in $24 \mathrm{~h}$ of incubation for both isolates, but more than $80 \%$ of conidia germinated after 6 days of incubation (data not shown). The percent conidial germination increased as temperature increased up to 20 or $25^{\circ} \mathrm{C}$ and then decreased rapidly from 25 to $30^{\circ} \mathrm{C}$ (Fig. 4E and F). The optimum temperature for conidial germination was between 20 to $25^{\circ} \mathrm{C}$ for both isolates. No conidial germination was observed at $35^{\circ} \mathrm{C}$ for either isolate, and macroconidia started to break down after $8 \mathrm{~h}$ of incubation.

Regardless of temperature, no conidial germination was observed in $3 \mathrm{~h}$ of wetness duration. Minimal wetness durations required for budding and developing germ tubes were temperaturedependent (Fig. 4). At 20 and $25^{\circ} \mathrm{C}$, macroconidia started budding to produce secondary conidia after a minimum wetness duration of 5 and $4 \mathrm{~h}$ for isolates 210 and 745, respectively, while 8 and $6 \mathrm{~h}$ of wetness durations were required for macroconidia to develop germ tubes for isolates 210 and 745, respectively (Fig. 4). In general, the percent conidial germination increased as wetness duration increased. At the optimum temperature, percent conidial germination reached its maximum after 20 or $24 \mathrm{~h}$ of incubation.

Germ tubes elongated at temperatures from 0 to $25^{\circ} \mathrm{C}$, but no elongation occurred at $30^{\circ} \mathrm{C}$. The optimum temperature for elongation was $20^{\circ} \mathrm{C}$ for both isolates. The average lengths of germ tubes were 116.2 and $141.3 \mu \mathrm{m}$ after incubation for $24 \mathrm{~h}$ at $20^{\circ} \mathrm{C}$ for isolates 210 and 745, respectively. Germ tubes elongated slowly at $0^{\circ} \mathrm{C}$, and the average length of germ tubes was 31.7 and $42.1 \mu \mathrm{m}$ for isolates 210 and 745, respectively, after 6 days of incubation (data not shown).

Effects of temperature and wetness duration on germination of secondary conidia. Secondary conidia germinated from 0 to $25^{\circ} \mathrm{C}$, and no germination was observed at $30^{\circ} \mathrm{C}$ for either isolate (Figs. 5 and 6). Germination of secondary conidia was observed after incubation for $20 \mathrm{~h}$ at 20 and $25^{\circ} \mathrm{C}, 48 \mathrm{~h}$ at $10^{\circ} \mathrm{C}$, and 9 days at $0^{\circ} \mathrm{C}$. For isolate 210 , the percentage of secondary conidia germinated by budding was significantly higher than those germinated by developing germ tubes after incubation for

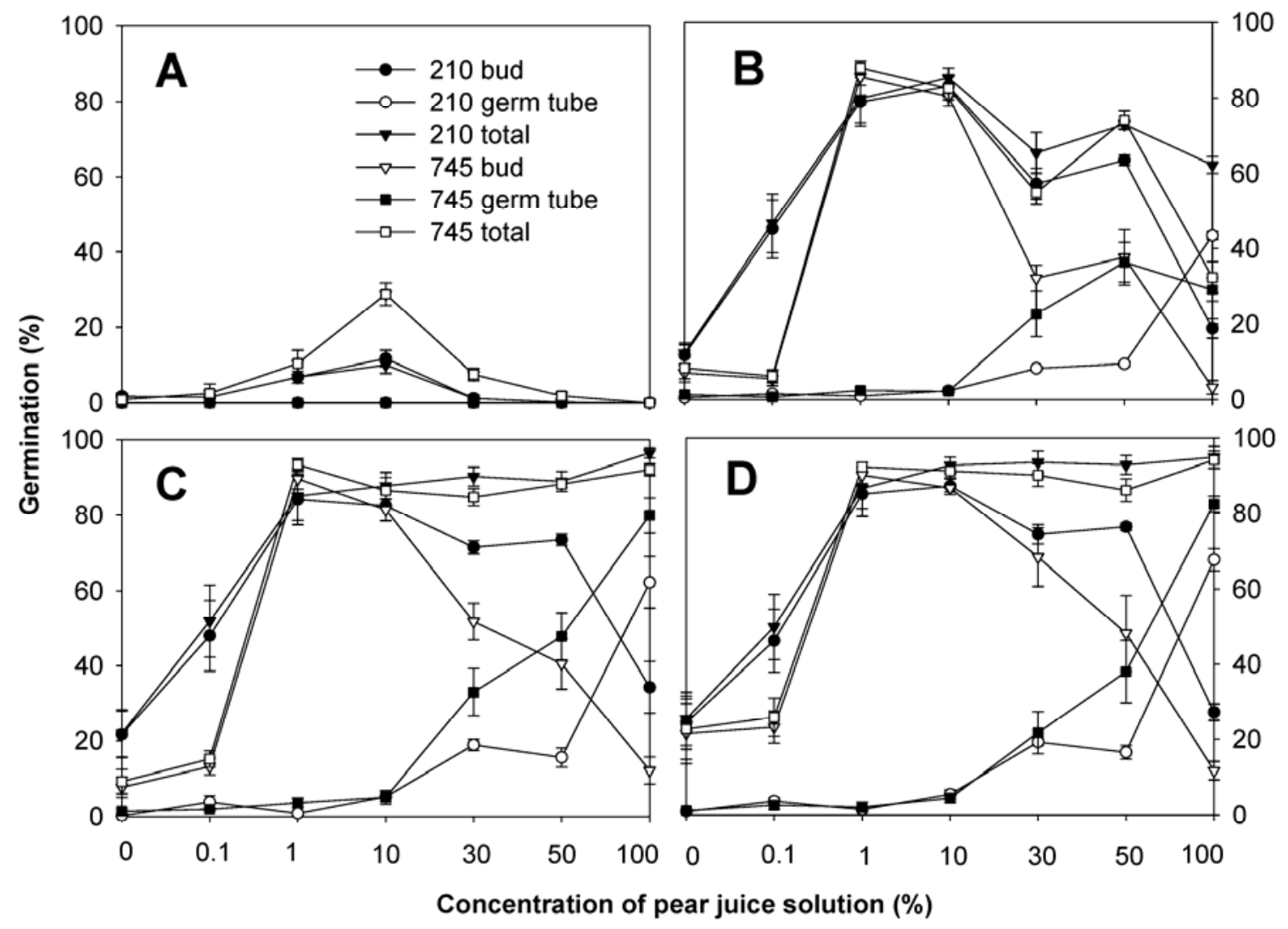

Fig. 2. Effect of nutrient level (concentration of pear juice) on germination of macroconidia of two isolates (210 and 745) of Potebniamyces pyri at $20^{\circ} \mathrm{C}$ after incubation for A, $6 \mathrm{~h}, \mathbf{B}, 12 \mathrm{~h}, \mathbf{C}, 18 \mathrm{~h}$, and $\mathbf{D}, 24 \mathrm{~h}$. Each data point represents the mean of two experimental runs each with three replicates at each nutrient level. Bars $=$ standard errors 
$36 \mathrm{~h}$ at $20^{\circ} \mathrm{C}$ ( $t$ test with $\left.P<0.0001\right)$ and $25^{\circ} \mathrm{C}(t$ test with $P=$ 0.002 ) and $60 \mathrm{~h}$ at $10^{\circ} \mathrm{C}$ ( $t$ test with $P=0.0067$ ) (Fig. 5A and $\mathrm{C}$ ). After incubation for 12 days at $0^{\circ} \mathrm{C}$, more secondary conidia germinated by germ tubes than by budding ( $t$ test with $P=$ 0.0011) (Fig. 6A). For isolate 745, the percentage of secondary conidia germinated by budding remained relatively stable after incubation for $30 \mathrm{~h}$ at $20^{\circ} \mathrm{C}$, whereas the percentage of secondary conidia germinated by germ tubes decreased as wetness duration increased from 30 to $42 \mathrm{~h}$; the percentage of conidia germinated by budding was significantly lower ( $t$ test with $P=0.0007$ ) than that germinated by germ tubes after $36 \mathrm{~h}$ at $25^{\circ} \mathrm{C}$. In general, at $10^{\circ} \mathrm{C}$ the percentage of secondary conidia germinated by budding increased, whereas those germinated by germ tubes decreased as wetness duration increased from 48 to $84 \mathrm{~h}$ (Fig. 5B and D). After
12 days at $0^{\circ} \mathrm{C}$, there was no significant difference between the percentage of germination by budding and that by germ tubes ( $t$ test with $P=0.1055$ ) (Fig. 6B).

Germ tubes of secondary conidia elongated at temperatures from 0 to $25^{\circ} \mathrm{C}$, and no germ tube elongation was observed at $30^{\circ} \mathrm{C}$. At $0^{\circ} \mathrm{C}$, elongation of germ tubes emerging from secondary conidia was observed after 8 or 9 days of incubation (data not shown).

Effect of RH on germination of macroconidia. At $20^{\circ} \mathrm{C}$, macroconidia did not germinate at 92 and $95 \% \mathrm{RH}$, even after $60 \mathrm{~h}$ of incubation. Macroconidia of both isolates germinated at 98 and $100 \%$ RH (Fig. 7).

At $20^{\circ} \mathrm{C}$ and $98 \% \mathrm{RH}$, macroconidia of both isolates germinated only by germ tubes, and after $60 \mathrm{~h}$ of incubation percent-

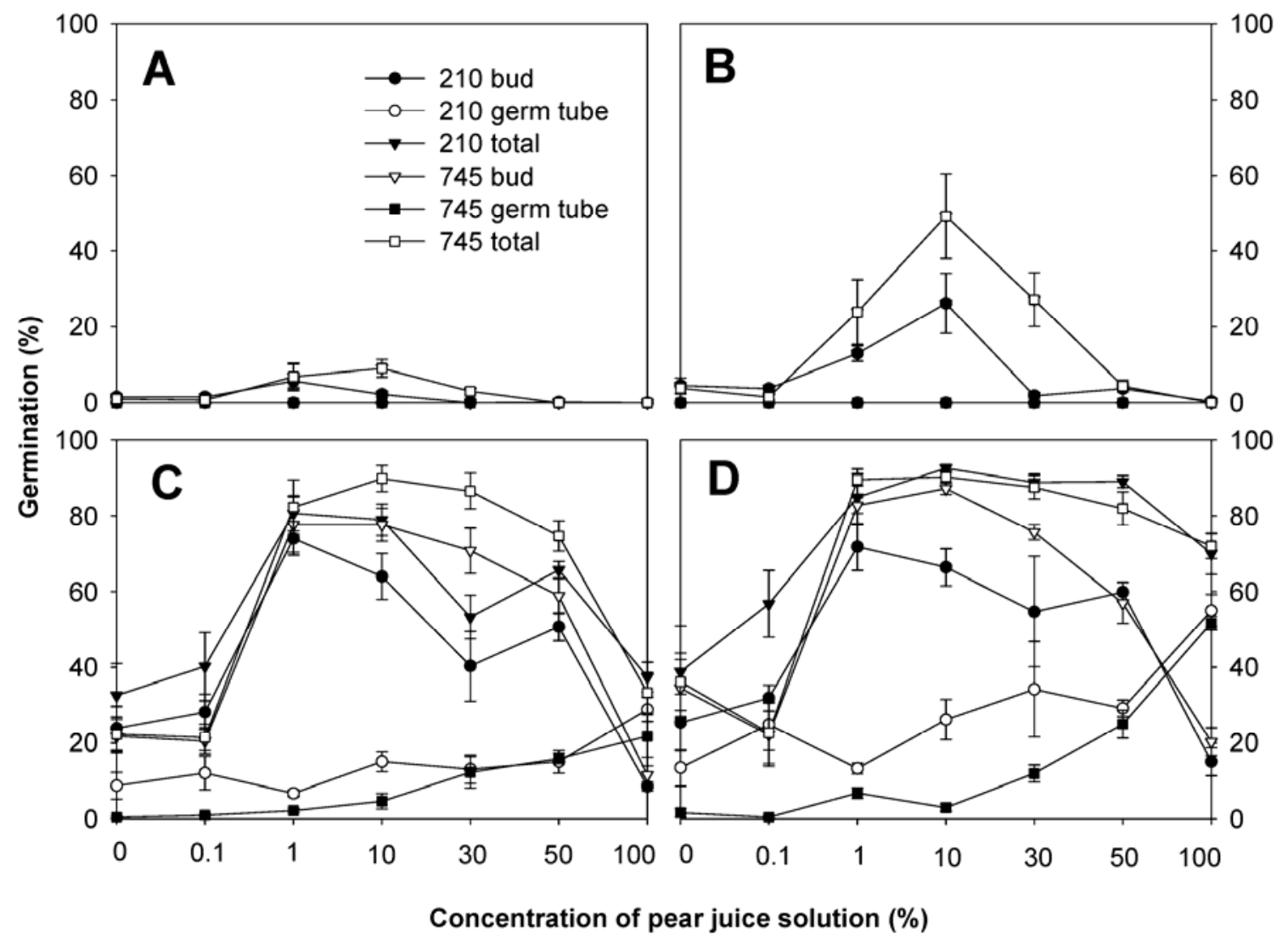

Fig. 3. Effect of nutrient level (concentration of pear juice) on germination of macroconidia of two isolates ( 210 and 745$)$ of Potebniamyces pyri at $0^{\circ} \mathrm{C}$ after incubation for $\mathbf{A}, 36 \mathrm{~h}, \mathbf{B}, 48 \mathrm{~h}, \mathbf{C}, 96 \mathrm{~h}$, and $\mathbf{D}, 120 \mathrm{~h}$. Each data point represents the mean of two experimental runs each with three replicates at each nutrient level. Bars $=$ standard errors.

TABLE 1. Analysis of variance of effects of temperature and wetness duration on conidial germination of Potebniamyces pyri

\begin{tabular}{|c|c|c|c|c|c|c|c|}
\hline \multirow[b]{2}{*}{ Data set } & \multirow[b]{2}{*}{ Source } & \multicolumn{3}{|c|}{ Total germination ${ }^{\mathrm{a}}$} & \multicolumn{3}{|c|}{$\%$ Budding in total germination ${ }^{\mathrm{b}}$} \\
\hline & & df & Mean square & $P>F$ & df & Mean square & $P>F$ \\
\hline \multirow[t]{5}{*}{ All wetness } & Isolate & 1 & 1.1258 & 0.0146 & 1 & 0.0268 & 0.1433 \\
\hline & Temperature & 5 & 10.5813 & $<0.0001$ & 3 & 0.2202 & $<0.0001$ \\
\hline & Wetness & 8 & 8.5269 & $<0.0001$ & 4 & 0.1282 & $<0.0001$ \\
\hline & Isolate $\times$ wetness & 8 & 0.0388 & $<0.0001$ & 4 & 0.0037 & 0.7333 \\
\hline & Temperature $\times$ wetness & 40 & 0.3697 & $<0.0001$ & 12 & 0.0161 & 0.0138 \\
\hline & Temperature & 5 & 1.9361 & 0.0001 & 3 & 0.0185 & 0.3723 \\
\hline & Isolate $\times$ temperature & 5 & 0.0122 & 0.2708 & 3 & 0.0359 & 0.1189 \\
\hline
\end{tabular}

${ }^{a}$ For total percentage of germination, six temperatures $\left(5,10,15,20,25\right.$, and $\left.30^{\circ} \mathrm{C}\right)$ were included for analysis; 0 and $35^{\circ} \mathrm{C}$ were not included because there was no germination within $24 \mathrm{~h}$ of wetness duration. Analysis was performed on pooled data from the two runs of the experiment. Preliminary analysis indicated that there were no experiment-treatment interactions.

${ }^{\mathrm{b}}$ For analysis on the percentage of budding in the total germination, four temperatures $\left(10,15,20\right.$, and $\left.25^{\circ} \mathrm{C}\right)$ were included. 
ages of germination were 40.2 and $32.2 \%$ for isolates 210 and 745, respectively (Fig. 7). After $60 \mathrm{~h}$ of incubation at $100 \% \mathrm{RH}$, the percentage of conidia of isolate 210 germinated by germ tubes (34.7\%) was significantly higher ( $t$ test with $P=0.0256$ ) than that by budding $(28.7 \%)$ (Fig. 7A and C). The vast majority of conidia of isolate 745 germinated by germ tubes, and the percentage was significantly higher than those germinated by budding after incubation for 48 and $60 \mathrm{~h}$ at $100 \% \mathrm{RH}$ ( $t$ test with $P<0.0001$ ) (Fig. 7B and D). In free water ( $0.1 \%$ pear juice solution), 48.2 and $53.5 \%$ of conidia of isolates 210 and 745 , respectively, germinated by budding, while $<10 \%$ conidia germinated by germ tubes after $60 \mathrm{~h}$ of incubation for both isolates (Fig. 7A to D).

At $0^{\circ} \mathrm{C}$, germination of macroconidia of both isolates was observed at $100 \% \mathrm{RH}$ but not at 95 and $98 \% \mathrm{RH}$. After incubation for 5 days at $100 \% \mathrm{RH}$, the percentage of conidia germinated by germ tubes was significantly higher than that by budding for both isolates: $10 \%$ by germ tubes versus $2.5 \%$ by budding ( $t$ test with $P=0.0172$ ) for isolate $210 ; 8.7 \%$ by germ tubes versus none by budding ( $t$ test with $P=0.0006$ ) for isolate 745 . In contrast, after incubation for 5 days in free water (in $0.1 \%$ pear juice solution), the percentage of conidia germinated by germ tubes was significantly lower than that by budding for both isolates: $5.2 \%$ by germ tubes versus $13.3 \%$ by budding ( $t$ test with $P=0.0003$ ) for isolate $210 ; 18.7 \%$ by germ tubes versus $27.2 \%$ by budding ( $t$ test with $P=0.0024$ ) for isolate 745 .

Germ tubes elongated at $\geq 98 \% \mathrm{RH}$. The average lengths of germ tubes were 49.6 and $31.1 \mu \mathrm{m}$ after $24 \mathrm{~h}$ of incubation at $100 \% \mathrm{RH}$ at $20^{\circ} \mathrm{C}$ for isolates 210 and 745 , respectively, and 71.2 and $50.6 \mu \mathrm{m}$ after $60 \mathrm{~h}$ of incubation at $98 \%$ at $20^{\circ} \mathrm{C}$ for isolates 210 and 745, respectively. The average lengths of germ
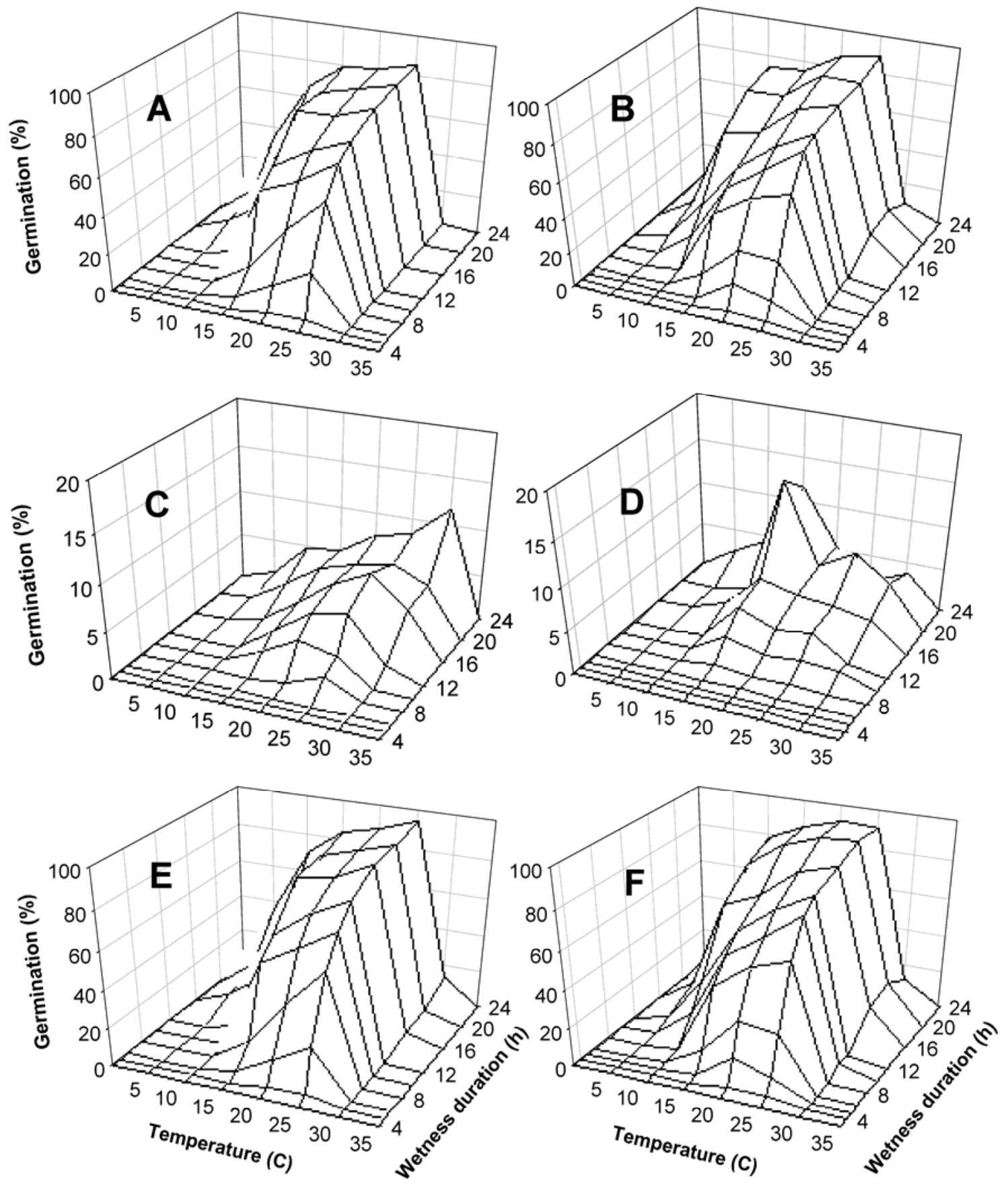

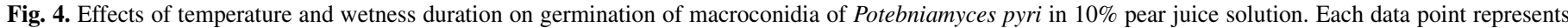

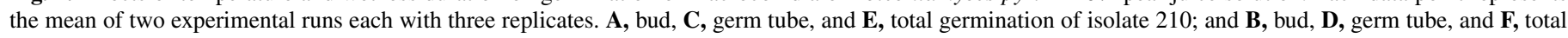
germination of isolate 745 . 
tubes were 9.3 and $13.3 \mu \mathrm{m}$ after 5 days of incubation at $100 \%$ $\mathrm{RH}$ at $0^{\circ} \mathrm{C}$ for isolates 210 and 745 , respectively (data not shown).

Effect of $\mathbf{p H}$ on germination of macroconidia. Macroconidia germinated at $\mathrm{pH} 3$ to 7 (Fig. 8). More than $80 \%$ of conidia germinated in $10 \%$ pear juice at $\mathrm{pH} 4$ to 7 after $24 \mathrm{~h}$ at $20^{\circ} \mathrm{C}$, while there was $<50 \%$ germination at $\mathrm{pH} 3 . \mathrm{pH}$ significantly affected mode of conidial germination. The percentage of conidia germinated by budding decreased as $\mathrm{pH}$ increased from 4 to 7
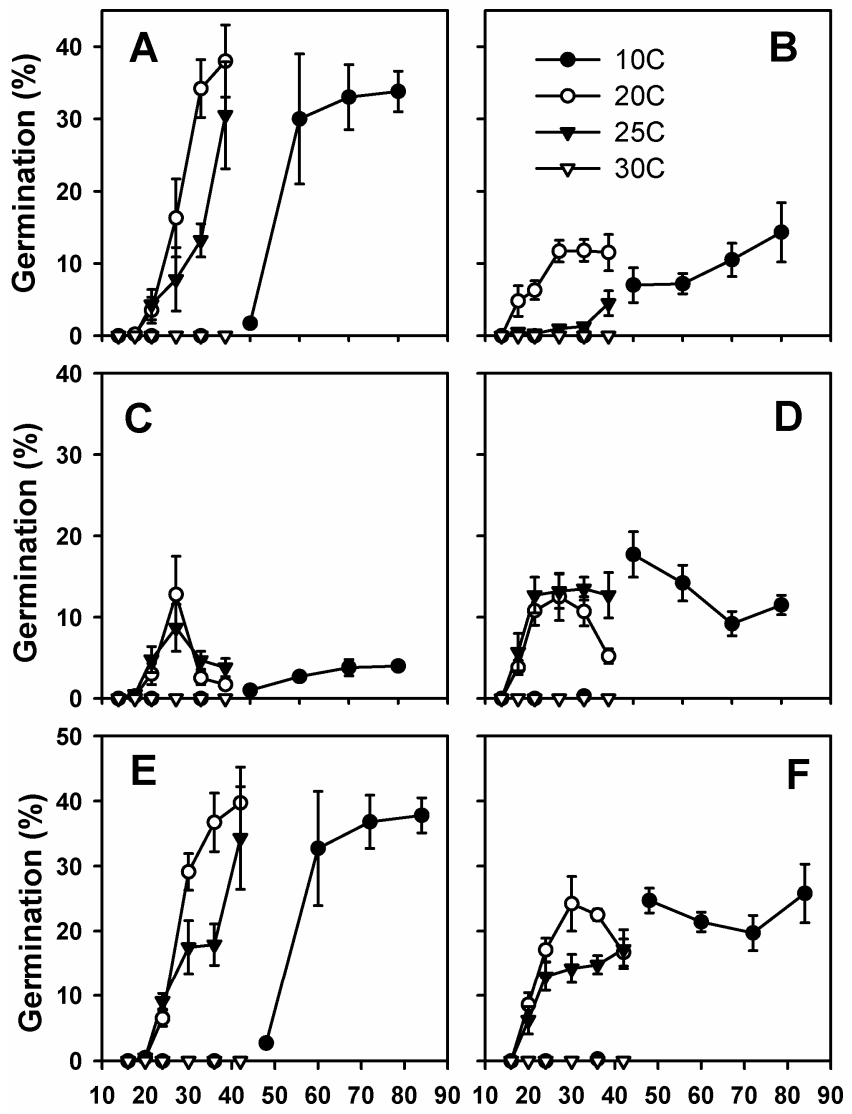

Wetness duration (h)

Fig. 5. Germination of secondary conidia of Potebniamyces pyri in $10 \%$ pear juice at different temperatures and wetness durations. Each data point represents the mean of two experimental runs each with three replicates. A, bud, C, germ tube, and $\mathbf{E}$, total germination of isolate 210; and $\mathbf{B}$, bud, D, germ tube, and F, total germination of isolate 745 . Bars = standard errors.

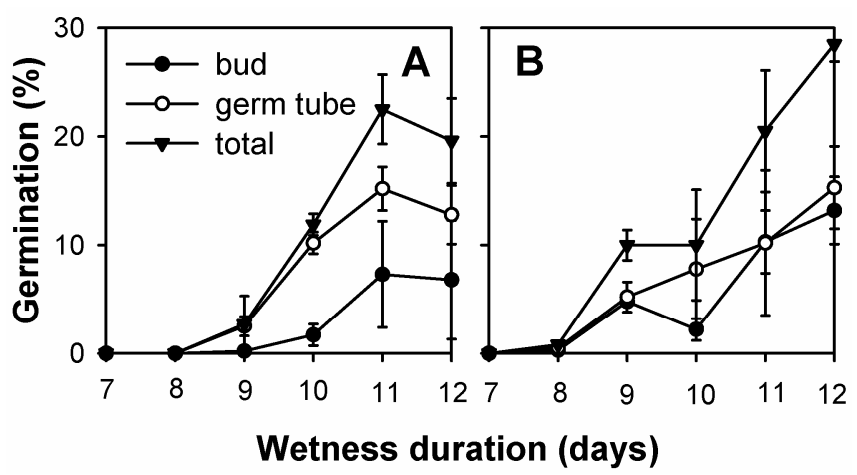

Fig. 6. Germination of secondary conidia of Potebniamyces pyri (A, isolate $210 ; \mathbf{B}$, isolate 745$)$ in $10 \%$ pear juice at $0^{\circ} \mathrm{C}$. Each data point represents the mean of two experimental runs each with three replicates. Bars $=$ standard errors. (isolate 210: $y=103.20-3.98 x, R^{2}=0.4401, P<0.0002$; isolate 745: $\left.y=112.32-7.3 x, R^{2}=0.4677, P<0.0001\right)$, whereas the percentage of macroconidia germinated by germ tubes increased as $\mathrm{pH}$ increased (isolate 210: $y=-15.00+4.08 x, R^{2}=$ $0.3593, P<0.0012$; isolate $745: y=-23.87+7.15 x, R^{2}=0.4434$, $P<0.0002)$.
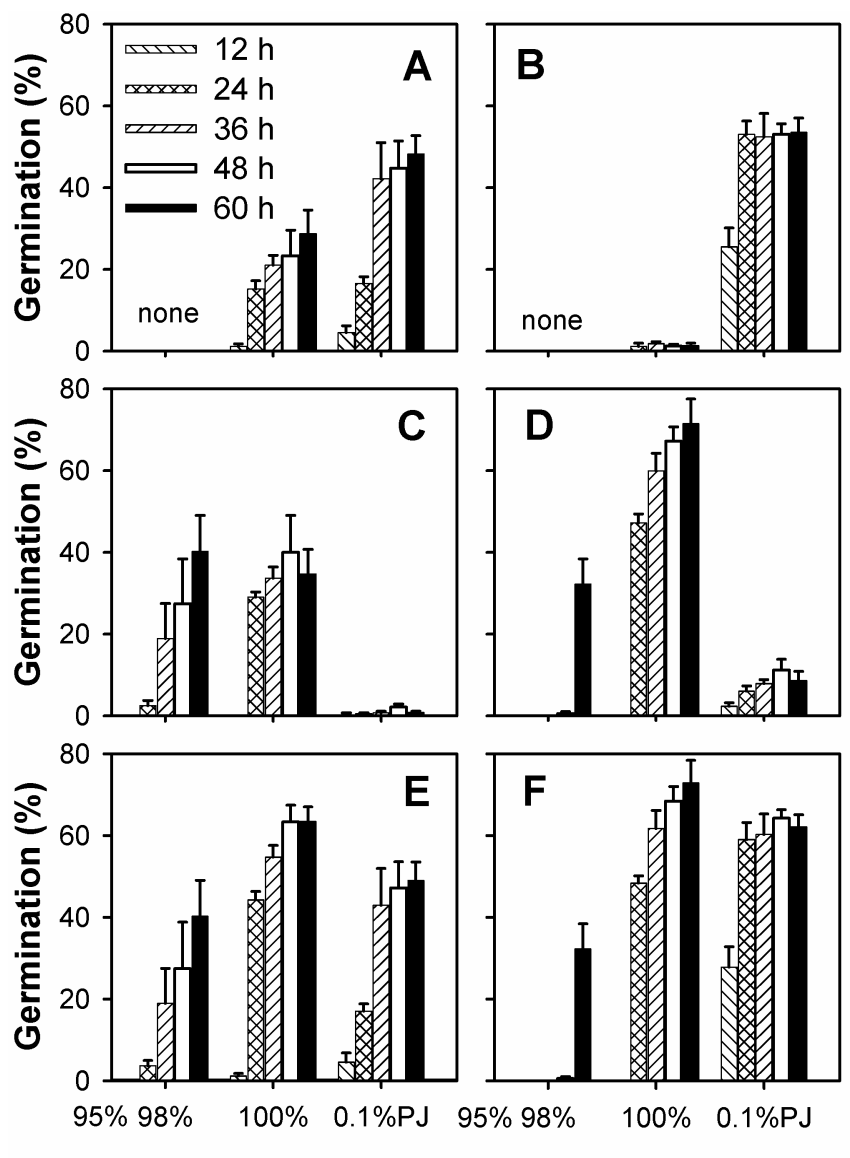

Relative humidity

Fig. 7. Effect of relative humidity (RH) on germination of macroconidia of Potebniamyces pyri at $20^{\circ} \mathrm{C}$. Each column represents the mean of two experimental runs each with three replicates. Bars $=$ standard errors. Conidial suspensions were made with $0.1 \%$ pear juice (PJ). Germination slides were first air-dried for $30 \mathrm{~min}$ in a laminar hood and then transferred to chambers with designated RH levels. Slides with conidial suspensions without air drying were also included as a free-water treatment. A, bud, $\mathbf{C}$, germ tube, and $\mathbf{E}$, total germination of isolate 210 ; and $\mathbf{B}$, bud, $\mathbf{D}$, germ tube, and $\mathbf{F}$, total germination of isolate 745 .
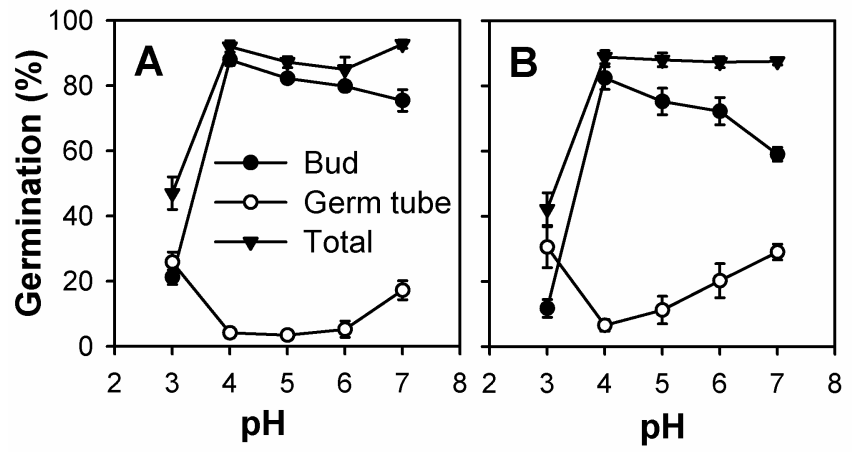

Fig. 8. Effect of $\mathrm{pH}$ on germination of macroconidia of Potebniamyces pyri $(\mathbf{A}$, isolate $210 ; \mathbf{B}$, isolate 745$)$ at $20^{\circ} \mathrm{C}$. Conidial suspensions were made with $10 \%$ pear juice, and $\mathrm{pH}$ was adjusted with $1 \mathrm{~N} \mathrm{NaOH}$ and $1 \mathrm{~N}$ succinic acid. Each data point represents the mean of two experimental runs each with three replicates. Bars $=$ standard errors. 


\section{DISCUSSION}

One of the distinct characteristics of $P$. pyri is that its conidia germinate in two different manners: budding and developing germ tubes. Potebnia (17) and Southee and Brooks (21) observed that budding was the dominant manner of germination of macroconidia of $P$. pyri, and they claimed that the germination by germ tubes is an exceptional manner of conidial germination. This may be because low-nutrient solutions or agar media were used in their studies. Potebnia (17) did not mention substrates used in the spore germination study, whereas apple wood-extract was used in the study by Southee and Brooks (21). In the present study, we documented that the mode of conidial germination of $P$. pyri was nutrient-dependent; low nutrient levels favored budding, whereas high nutrient levels favored development of germ tubes. To our knowledge, this is the first report of nutrient effects on the mode of conidial germination of $P$. pyri. Both Potebnia (17) and Southee and Brooks (21) observed germination of secondary conidia by producing germ tubes, which later develop into hyphae, but they did not observe germination of secondary conidia by budding. In the present study, we observed that secondary conidia, produced by budding of mother macroconidia, can also germinate by budding to produce more new, secondary conidia. The two-type mode of conidial germination is likely a strategy of the fungus for ecological adaptation. Conidia of $P$. pyri are waterdispersed (6). Conidia of the fungus may encounter environments with different nutrient levels in the orchard. For example, honeydew produced by pear psylla (Cacopsylla pyricola) may create a nutrient-rich microenvironment on the surface or stem of fruit. When nutrient is available and other environmental conditions are met, conidia of the fungus may directly develop germ tubes, which develop hyphae and penetrate host tissues, whereas in a lownutrient environment most conidia germinate by budding. One conidium can produce many secondary conidia through budding, which would increase the amount of inoculum of the fungus; presumably these free, secondary conidia are readily dispersed by water or insects and may serve as an important source of inoculum in the orchard.

Potebnia (17) observed that ascospores of $P$. pyri germinate in the same manner as macroconidia, mainly by budding and occasionally by emerging germ tubes. In north-central Washington State, apothecia of $P$. pyri occur in pear orchards but at a very low frequency (28). In the present study, germination of ascospores in response to nutrient levels and environmental factors was not determined because of the unavailability of ascospore inoculum for the study. We have tried to produce apothecia on sterilized pear woods in laboratory conditions without success (C. L. Xiao, unpublished data).

Mycelium of $P$. pyri grows at temperatures ranging from -3 to $25^{\circ} \mathrm{C}$ with optimal growth at $20^{\circ} \mathrm{C}$, and no mycelial growth occurs at $30^{\circ} \mathrm{C}(29)$. The results of macroconidial germination and germ tube elongation in response to temperature are in general agreement with temperature responses of mycelial growth of the fungus (29). We observed that secondary conidia germinated at temperatures from 0 to $25^{\circ} \mathrm{C}$ but not at $30^{\circ} \mathrm{C}$, indicating that infection of pear fruit by conidia might not occur at $30^{\circ} \mathrm{C}$ because germ tubes do not elongate and secondary conidia do not germinate at this temperature. This may also indicate that germination through budding may not be an efficient way for the fungus to establish infection in comparison with germination through germ tubes because at least a 20 -h wetness duration is required for secondary conidia, produced by mother macroconidia, to germinate, while at 20 and $25^{\circ} \mathrm{C}$ only 6 to $8 \mathrm{~h}$ of wetness is needed for macroconidia to directly develop germ tubes.

D'Anjou pears are commercially stored at -1.1 to $0.5^{\circ} \mathrm{C}(15)$. One type of Phacidiopycnis rot symptoms on d'Anjou pears is the decay originating from infection of wounds on the surface of the fruit at harvest. Because conidia of P. pyri germinated in $100 \%$ pear juice solution at $0^{\circ} \mathrm{C}$ as shown in the present study and mycelium is able to grow at $-3^{\circ} \mathrm{C}(29)$, this indicates that low temperatures used for storage of pears cannot prevent development of the disease during storage.

The effect of temperature on the mode of conidial germination, expressed as percentage of budding in the total conidial germination, was dependent on wetness duration (Table 1). At $24 \mathrm{~h}$ of wetness duration, the percentage of budding in the total conidial germination was not significantly affected by temperatures ranging from 5 to $30^{\circ} \mathrm{C}$. In addition, the averages of percentage of budding in the total germination were $>60 \%$ at all temperatures tested (data not shown), indicating that budding is the most common mode of conidial germination in $10 \%$ pear juice in the in vitro test, regardless of temperature (Fig. 4). Although conidial germination of the two isolates responded to temperature and wetness duration differently to some extent, budding as a percentage of total germination was not significantly affected by isolate (Table 1), suggesting that the mode of conidial germination, i.e., germination primarily by budding, was not an isolate-dependent phenomenon in $P$. pyri.

In comparison with germination of macroconidia, inconsistency in germination of secondary conidia in response to temperature and wetness duration was observed (Fig. 5E and F). The percentage of secondary conidia germinated by germ tubes either decreased or remained relatively stable at 20 and $25^{\circ} \mathrm{C}$ as wetness duration increased from 30 to $42 \mathrm{~h}$ and at $10^{\circ} \mathrm{C}$ as wetness duration increased from 48 to $84 \mathrm{~h}$ (Fig. 5C and D). This was likely due to budding of the second generation of secondary conidia. After $30 \mathrm{~h}$ of incubation, secondary conidia of different generations coexisted at the same time, and ages of some secondary conidia were not readily differentiated. Thus, the number of young secondary conidia increased, resulting in a decrease in percentage of germination of secondary conidia because additional time was needed for newly produced secondary conidia to germinate.

Conidia of some other fruit-rotting fungal pathogens in apple and pear can germinate at $\mathrm{RH}$ as low as $92 \%$ at their optimal temperatures $(1,16,22)$. Results of our study showed that macroconidia of $P$. pyri were able to germinate at $\geq 98 \% \mathrm{RH}$ at $20^{\circ} \mathrm{C}$ and at $100 \% \mathrm{RH}$ at $0^{\circ} \mathrm{C}$, indicating that a higher $\mathrm{RH}$ is required for conidial germination of $P$. pyri than for some other fungal pathogens. Our results also indicate that moisture level affected the mode of conidial germination of $P$. pyri. Higher RH $(\mathrm{RH} \geq 98 \%)$, but not free water, favored development of germ tubes, whereas free water favored budding (Fig. 7). This may be due to the difference in oxygen supply between high $\mathrm{RH}$ (such as $\mathrm{RH} \geq 98 \%$ ) without the presence of free water and free water drops used for conidial germination in our study. Spore germination and mycelial growth of the same fungus may have different sensitivities to reduced oxygen (11). Mycelial growth of Botrytis cinerea and Alternaria tenuis required greater oxygen levels than spore germination (23). Different patterns in response to RH between budding and development of germ tubes may also be a strategy of P. pyri for its adaptation to environment. For example, when free water is available, the fungus may augment its inoculum through budding to produce more secondary conidia, which can be readily dispersed by water, whereas under high $\mathrm{RH}$, when nutrient is available conidia directly develop germ tubes, which can develop hyphae and penetrate host tissues to establish infection.

When nutrient requirements are satisfied, most fungi grow well over a broad range of $\mathrm{pH}$ values from 4 to 7 (5). Mycelium of P. pyri grows well at $\mathrm{pH} 3.2$; the optimal $\mathrm{pH}$ for mycelial growth is around $\mathrm{pH} \mathrm{4}$; and mycelial growth declined rapidly when $\mathrm{pH}$ was increased from 4 to 6 (29). In the present study, we observed that the total percentage of conidia that germinated was not significantly affected by $\mathrm{pH}$ values ranging from 4 to 7 , but the manner of conidial germination was significantly affected by $\mathrm{pH}$ (Fig. 8). Over the range of $\mathrm{pH}$ from 4 to 7 , lower $\mathrm{pH}$ favored budding, whereas higher $\mathrm{pH}$ favored development of germ tubes. 
The coexistence of both modes of conidial germination and their differential responses to $\mathrm{pH}$ may explain the difference in response to $\mathrm{pH}$ between conidial germination and mycelial growth.

The germination of conidia by the direct formation of secondary conidia, without the intervention of mycelial growth, is called microcycle conidiation (12), which has been described in many fungal species (11), including plant-pathogenic fungi $(2,7$, 14,18). Microcycle conidiation has been suggested as a survival mechanism when unfavorable conditions are encountered (12). Little research has been done to quantify environmental effects on microcycle conidiation in plant pathogens $(12,14)$. In the present study, we have identified several factors that affect the model of conidial germination of $P$. pyri and further defined the relationships between these factors and conidial germination. The results contribute to the knowledge of the biology and ecology of $P$. pyri and sources of secondary inoculum for diseases it causes and to an understanding of environmental conditions required for infection of fruit by the fungus leading to Phacidiopycnis rot.

\section{ACKNOWLEDGMENTS}

Plant Pathology New Series 0385, Project 0367, College of Agricultural, Human, and Natural Resource Sciences, Washington State University. We thank J. D. Rogers for assistance in preparing micrographs of conidial germination. This research was supported in part by the WSU Agricultural Research Center Graduate Research Assistant Enhancement Program, the Winter Pear Control Committee, and the Washington Tree Fruit Research Commission.

\section{LITERATURE CITED}

1. Arauz, L. F., and Sutton, T. B. 1989. Influence of temperature and moisture on germination of ascospores and conidia of Botryosphaeria obtusa. Phytopathology 79:667-674.

2. Bandyopadhyay, R., Mughogho, L. K., Manohar, S. K., and Satyanarayana, M. V. 1990. Stroma development, honeydew formation, and conidial production in Claviceps sorghi. Phytopathology 80:821-818.

3. Barthelet, J. 1943. Recherches sur quelques parasites des arbres fruitiers. Ann. Epiphyties 9:27-45

4. Brooks, F. T. 1928. On the occurrence of Phacidiella discolor (Mout. \& Sacc.) Potebnia in England. Trans. Br. Mycol. Soc. 13:75-81.

5. Carlile, M. J., Watkinson, S. C., and Goody, G. W. 2001. The Fungi. 2nd ed. Academic Press, London.

6. DiCosmo, F., Nag Raj, T. R., and Kendrick, W. B. 1984. A revision of the Phacidiaceae and related anamorphs. Mycotaxon 21:1-234.

7. Fernandez, F. A., Glawe, D. A., and Sinclair, J. B. 1991. Microcycle conidiation and nuclear behavior during conidiogenesis in Cercospora kikuchii. Mycologia 83:752-757.

8. Ficke, W., and Peter, E. 1982. Occurrence of apple bark necrosis pathogens so far not identified in the German Rep. Dem. Arch. Phytopathol. U. Pflanzenschutz 18:31-38.
9. Gomez, K. A., and Gomez, A. A. 1984. Statistical Procedures for Agricultural Research. 2nd ed. John Wiley \& Sons, New York.

10. Gomori, G. 1955. Preparation of buffers for use in enzyme studies. Pages 138-146 in: Methods of Enzymology. S. P. Colowick and N. O. Caplan, eds. Academic Press, New York.

11. Griffin, D. H. 1994. Fungal Physiology. 2nd ed. John Wiley \& Sons, New York.

12. Hanlin, R. T. 1994. Microcycle conidiation-a review. Mycoscience 35:113-123.

13. Johnson, C. G. 1940. The maintenance of high atmospheric humidities for entomological work with glycerol-water mixtures. Ann. Appl. Biol. 27:295-297.

14. Lapaire, C. L., and Dunkle, L. D. 2003. Microcycle conidiation in Cercospora zeae-maydis. Phytopathology 93:193-199.

15. Meheriuk, M. 1993. CA storage conditions for apples, pears, and nashi. Pages 819-841 in: Proceedings from the Sixth International Controlled Atmosphere Research Conference, Cornell University, Ithaca, NY.

16. Ocamb-Basu, C. M., and Sutton, T. B. 1988. Effects of temperature and relative humidity on germination, growth, and sporulation of Zygophiala jamaicensis. Phytopathology 78:100-103.

17. Potebnia, A. 1912. Ein neuer Krebserreger des Apfelbaumes Phacidiella discolor (Mout. Et Sacc.) A. Pot., seine Morphologie und Entwickelungsgeschichte. Zeit Pflanzenkrank. 22:129-153.

18. Rathaiah, Y. 1977. Stomatal tropism of Cercospora beticola in sugarbeet. Phytopathology 67:358-362.

19. Sharma, R. L. 1991. Prevalence of storage rots of China pear in Himachal Pradesh. Plant Dis. Res. 5:109-111.

20. Snowdon, A. L. 1992. Post-Harvest Diseases and Disorders of Fruits and Vegetables. Vol. 1. General Introduction and Fruits. CRC Press, Boca Raton, FL.

21. Southee, E. A., and Brooks, F. T. 1926. Notes on a pycnidial fungus associated with a dying-back of apple branches. Trans. Br. Mycol. Soc. 11:213-219.

22. Sutton, T. B., and Arauz, L. F. 1991. Influence of temperature and moisture on germination of ascospores and conidia of Botryosphaeria dothidea. Plant Dis. 75:1146-1149.

23. Wells, J. M., and Uota, M. 1970. Germination and growth of five fungi in low oxygen and high carbon dioxide atmosphere. Phytopathology 60:5053 .

24. Wollenweber, H. W. 1937. Der schwarze Rindenbrand der Quitte. Angewandte Bot. 19:131-140.

25. Xiao, C. L., and Boal, R. J. 2002. Pathogenicity and infection courts of Phacidiopycnis piri in pears. (Abstr.) Phytopathology 92(suppl.): S88.

26. Xiao, C. L., and Boal, R. J. 2003. Distribution of Potebniamyces pyri in the Pacific Northwest and its association with bark necrosis and canker on twigs of pear trees. (Abstr.) Phytopathology 93(suppl.):S92.

27. Xiao, C. L., and Boal, R. J. 2004. Prevalence and incidence of Phacidiopycnis rot in d'Anjou pears in Washington State. Plant Dis. 88:413418.

28. Xiao, C. L., and Boal, R. J. 2004. Inoculum availability and seasonal survival of Potebniamyces pyri in pear orchards. (Abstr.) Phytopathology 94(suppl.):S112.

29. Xiao, C. L., and Sitton, J. W. 2004. Effects of culture media and environmental factors on mycelial growth and pycnidial production of Potebniamyces pyri. Mycol. Res. 108:926-932. 